\title{
Branding Strategy: How Pasar Kebon Empring can Survive During Pandemic Outbreak
}

\author{
Aisha Astriecia ${ }^{1}$, Septi Riana Dewi ${ }^{1}$ \\ aisha.astriecia@gmail.com, riaarkana75@gmail.com \\ ${ }^{1}$ Universitas Teknologi Yogyakarta, Indonesia
}

\begin{abstract}
The Covid-19 outbreak has affected various strategic sectors all over the world. One of them is the tourism sector. Pasar Kebon Empring (PKE) as one of the tourism destinations in Yogyakarta also faces some challenges during the pandemic since the government regulation limiting the access of people gathering in a large number. This paper aims to illustrate the branding strategy of PKE and the challenges faced during the pandemic. The theory of branding strategy proposed by Kotler (2009) was employed in this study. The descriptive qualitative method is used in this study. The result of the study shows that PKE poses a natural atmosphere as its brand positioning, positive impression toward the service was also gained from the visitors as its brand personality, and various traditional culinary and bamboo stuff were indicated its brand identity. Moreover, dealing with the decreased number of visitors, the management of PKE provided some promotion media to secure visitor's safety.
\end{abstract}

Keywords: PKE, Tourism, Branding strategy, Pandemic,

\section{Introduction}

The tourism sector plays an important role in economic progress in Indonesia. Data from the 2019 Ministry of Tourism shows that since 2013 the tourism sector has made the largest contribution besides oil, coal, and palm oil. ${ }^{2}$ Indonesia has high hopes for the sustainability and progress of the tourism sector. Tourism activities are part of the needs that are in demand from the family segment to the millennial generation group. Today, tourism behavior has several unique characteristics, including being spontaneous and unplanned, ignoring conventional marketing, and being highly dependent on information obtained via smartphones and social media. ${ }^{3}$ Unfortunately, the current condition of the well-formed tourism behavior had to stop suddenly due to the Covid-19 pandemic. Since March 11, 2020, WHO has officially given the status of a global pandemic which has resulted in stagnation or a slowdown in various economic activities in the world, including the tourism sector. Based on WHO recommendations in reducing the spread of infection, the policy of physical restrictions by reducing physical contact with other people and avoiding gathering activities have a significant impact on the tourism sector. ${ }^{4}$ This fact was also agreed by the chairman of the National Entrepreneurs Network (JAPNAS) that the tourism sector is one of the businesses 
most affected by Covid-19. Worse, the tourism industry is projected to be the last sector to recover after this pandemic period ends. According to the World Travel and Tourism Council (WTTC), it is estimated that it will take 10-35 months for the tourism industry to return to normal. Therefore, it is very necessary to prepare optimal strategies in accelerating the recovery of the tourism industry. The Less Contact Economy agenda and the 'right' marketing strategy with current conditions and needs are ways to prepare for the new normal life of tourism in Indonesia. Tourism which is just starting to grow in many SMEs in the Tourism sector in Indonesia needs to be maintained and cared for to stay alive until the end of this pandemic disaster. This tourist village was founded against the backdrop of the Cempaka Storm disaster on 27-29

November 2017 knocked down the connecting bridge between RTs in Bintaran Village. Disaster moves the surrounding community to change the damaged location in Bintaran Village to become a new tourist location by offering the concept of leisure tourism. Meaning of Leisure tourism is a tourist activity to unwind for a moment by relaxing and enjoying nature. This tourist location is unique with many growing bamboo trees around the river. Therefore, this tour was named Bon Pring Tourism, which in Bahasa Indonesia Javanese means "Bon" is Garden and "Pring" is Bamboo. The attraction of "Bon" tourism Pring" according to our observations is a new experience eating food on the river using lincak, a variety of typical village culinary offerings at affordable prices, a place to relax in the form of bamboo gazebo, live music, and a suspension bridge. Every day, Bon Pring tours are opened at 10.00-17.00 (weekdays) and 07.00-17.00 (weekends), by involving the personnel of the Bintaran Village Tourism group every day as at the following: 34 food sellers, 22 assistants, and 1 manager. Visitors who come on weekdays range from 50-100 people, while on weekends it can reach $>1000$ people. Condition Visitors also experience changes from before the pandemic and in the era of the Covid-19 pandemic.

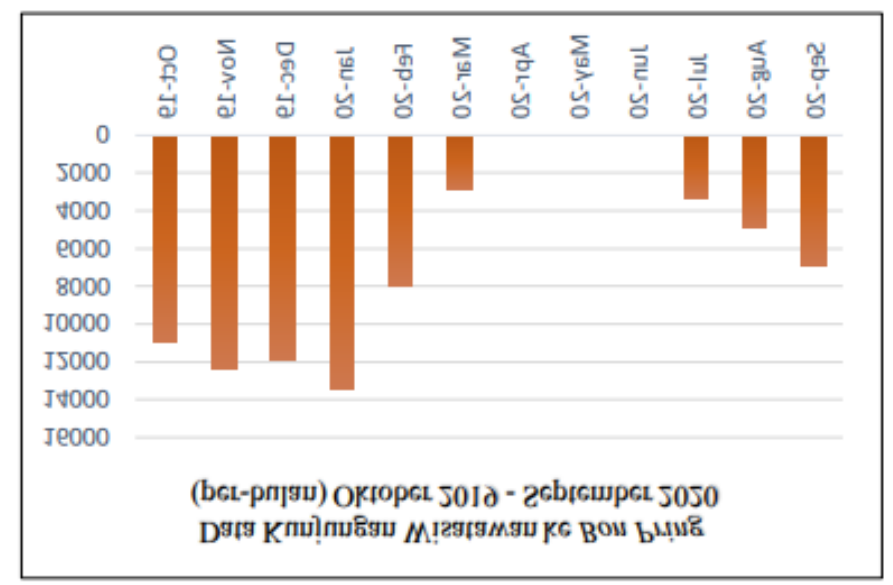

Figure 1. Data on the Number of Visitors to Bon Pring Before and Amid the Pandemic

Since the implementation of the new normal or the adaptation period to the new normal, Pasar Kebon Empring has also made improvements. PKE welcomes this policy as tourism is an inseparable part of human needs who need the entertainment to get peace and comfort. As a new potential tourist destination, PKE team continues to make some efforts to secure the visitors that this place is feasible and safe to visit during the enactment of the new normal. 
This paper aims to illustrate the branding strategy of PKE and the challenges faced during the pandemic.

\section{Theoretical Review}

Brands have more value than the just a product because the product is an item that a factory produced, while the brand is something that consumers buy. ${ }^{5}$ Consumers buy an item, not just need for the function of the item, however more than that, the brand of the item has a value that makes consumers choose a product. As an identity, Brand also has benefits that can bring a positive perception for the consumer. The power of branding is considered to have significant enough that it can build brand awareness which in the end increases the selling value. $^{6}$

In addition to the brand, reputation is an important part of the formation of a brand. Brand and reputation have a mutually influencing relationship with each other. Reputation becomes urgent so that what is offered by a brand can be accepted well by the audience. This is inseparable from the demands of society as consumers are getting longer the higher it is. This demand is in line with the increasing critical power of society. A company that always strives to maintain its reputation tends to get support from the community. The thing that the same applies to the government. ${ }^{7}$

\section{The Role of Branding}

In the business world, the existence of branding has a very important role, especially for consumers. Keller in Fandi Tjiptono ${ }^{8}$, mentions that there are seven benefits branding, including the following: 1) as product source identification; 2) determination responsibility on the manufacturer or distributor certain; 3) signal quality; 4) tool for projecting self-image; 5) specialties with manufacturers; 6) suppression of internal and external search costs; 7) risk reduction.

The existence of a brand (brand) becomes a value indicator for all stakeholders, including staff, managers, investors, and customers. Products that have a more valuable brand in the eyes of consumers than products that don't have a brand. ${ }^{9}$

\section{Branding Strategy}

According to Kotler ${ }^{10}$, branding strategy has several components as follows:

1) Brand Positioning

Brand positioning is a strategic marketing that has the function of making the difference between benefits and advantages specific for consumers so that they can remember the brand. Brand positioning tourism has the intention of making it easy for tourists to distinguish between a tourist place and other tourist spots. Good positioning of course will produce a good impact and response 
from the market. Positioning can also create the existence and credibility of a product or service.

2) Brand Personality

Brand Personality is an effort for the company or business actor to add plus value for a brand from the outside in the eye's consumer. Ways to add plus and the appeal of a brand is through experience with other consumers, or it can be through communication marketing that introduces the brand itself. This method can also help marketing parties to understand where the advantages and disadvantages

A brand so that it affects the right way to promote the product. ${ }^{11}$

3) Brand Identity

According to Susanto and Wijarnoko (Susanto, 2004) ${ }^{12}$; Brand identity is a series of words, impressions

and a number of perceptions from consumers about brand or brand of a product. There is a brand identity can help identify perceptions consumers about a brand.

Tourism Destination Development

Several components need to be fulfilled in the development of tourism destinations, including the following ${ }^{13}$ :

a. Attraction, namely the attraction of a tourism object that includes potential-based Attractiveness

natural wealth, cultural uniqueness, and artificial man.

b. Accessibility, including system support transportation to tourism access, such as tool transportation, transportation routes, terminal facilities, airports, or ports and modes of other transportation.

c. Amenity, including activities supporting facilities tourism, such as lodging, houses of worship,

resting place, restaurant, shop souvenirs, exchange or disbursement facilities money, tourist information centers, travel agents, and other required facilities

\section{Method}

In this study, the writers used the qualitative method with interviews, observations, and documentation for data collection to obtain the objective data. Qualitative research is research procedures that create data descriptive in the form of words and behavior from the people studied. The data source of this study pays attention to three instruments on research on qualitative types, namely actors (actors), activity (activity), and place (place). ${ }^{14}$

The object of this study is how PKE branding strategy as a tourist destination in times of pandemic is. As for data collection techniques is done in several ways, interviews, observations, and documentation. Observation is to see the daily activities carried outsource person. Interview is a process obtain information for research purposes by way of question and answer face to face between the questioner (interviewer) and the person in charge (informants) by using tools called the interview guide. Documentation is carried out for looking for data about things that are considered relevant to research which includes: books, 
newspapers, biographies, notes, transcripts, magazines, agendas, inscriptions, meeting minutes, and so on.

\section{Findings and Discussion}

\subsection{Branding Strategy of PKE during the pandemic Covid-19}

The implementation of the new normal applied by the government since the beginning of June 2020 is giving a chance the economy sector to move, including in the tourism sector, which previously had discontinued. This is because tourism is considered by a sector that can create to extend for regional and even national economic sectors. The opening of the tourism sector also continues to apply health protocol.

Then, to increase the tourism potential of PKE, the Ministry of Research and Technology at the beginning of 2020 is here to aid in the form of handwashing facilities. Hand washing infrastructure is installed in the front area before entering the main door. Other help also comes from KEMENPARKRAF in mid-October 2020 by providing some funds for additional infrastructure construction, such as huts and repair of visitor trails in PKE tourist area. However, these two aids have not been felt useful its significance to the core problems faced by PKE. This assistance is deemed not to have targeted the main needs of PKE, namely: branding to support revisit.

Brand positioning aims to create differences, benefits, advantages that make consumers always remember a product. Relation to tourism, brand positioning in the field of tourism aims to help visitors identify the unique differences between one destination with another destination. Branding is considered as the process through which a brand is established by adding capitalized value to the service of product. ${ }^{15}$ Moreover, branding is not a method but rather an acquired imaged. ${ }^{16}$

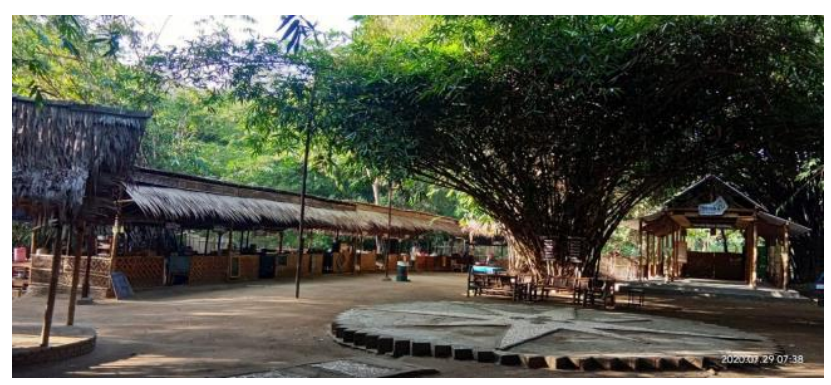

Figure 2. Pasar Kebon Empring

Pasar Kebon Empring was founded in 2017 since Cempaka Hurricane disaster knocked down the connecting bridge between community housing in Desa Bintaran Wetan, thus moving the surrounding community to turn Bintaran Wetan area into a new tourist location that offers leisure tourism. Another motivation for the local community in 
establishing this area is to use the existing bamboo gardens along the river as an attraction and economic improvement for the local community. The first tourist destination was initiated by Bintaran Wetan, known as Kebon Empring Tourism. This is the first tourist destination established in Dusun Bintaran area. Visitors can enjoy various village specialties at very affordable prices, the experience of eating food by the river (leisure tourism), a place to relax in the form of a gazebo made of bamboo, live music, suspension bridges, and an art corner.

Brand personality is the consumer's impression or visitors in tourism services in PKE. This impression or opinion includes a good impression (positive) and a bad impression (negative). Impression or opinion of this consumer is expected to be materials for tourism managers to improve the service.

Based on an interview with one of the visitors, PKE has a very suitable area to unwind during the pandemic. The breeze that blows between the bamboo trees and the riverbank of Kaligawe can calm visitors. ${ }^{17}$

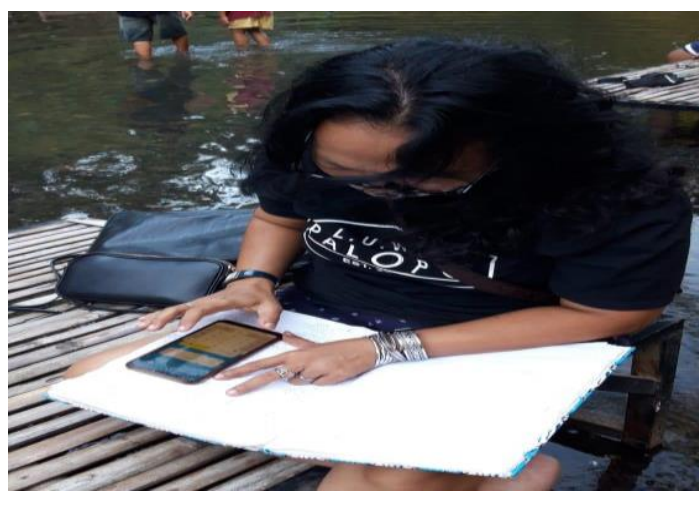

Figure 3. Interview with Titik Ai Luh (Manager of PKE)

To secure the condition around PKE. The manager of PKE often checks the data of the visitor during the pandemic. She regularly reports the number visitors to Tourism Department of Bantul. It belongs to PKE responsibility.

Brand Identity includes the hallmarks and icons owned by PKE as a tourist destination. Based on interviews with stakeholders and visitors. The advantage of PKE lies in the conditions geographical location that offers natural tourist locations strategic enough to be used as a tourist spot. 


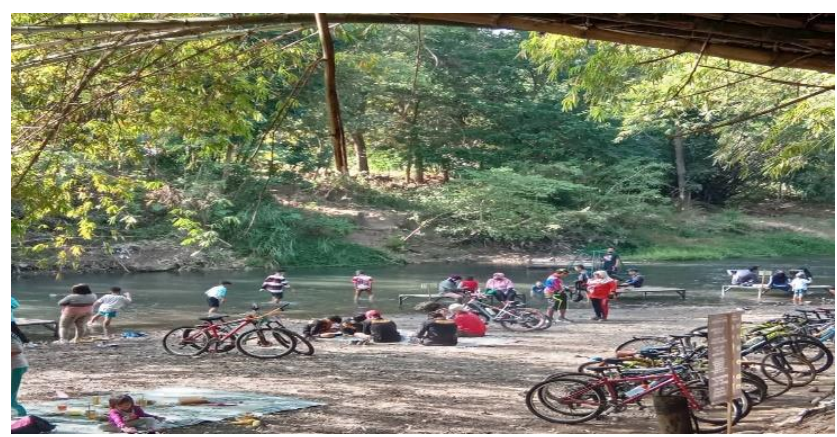

Figure 4. The riverbank of Kaligawe

Brand Positioning, Brand Personality, and Brand Identity is carried out through tourism promotion efforts with the use of mass media, both media mainstream and online media. Usually, promotions can be done in crowded places like exhibitions, music concerts, bazaars, and so on, but during this pandemic, promotions can only be done through the media, especially social media. ${ }^{18}$ It is in line with Assenov \& Khurana stressing out that social networking sites are originally used for entertainment purposes, however an increase in the use of the internet and information communication technologies has shifted the way people communicate each other, mainly in the hospitality and tourism industries. ${ }^{19}$

\subsection{Challenges faced by PKE}

The community's need for relaxation through tourism becomes an opportunity, however it is a challenge on the other. The challenge none other than the ongoing spread of covid 19 increase makes some people still afraid to travel and do tours. It is sure to have an impact on the income of managers and food sellers in PKE areas which is not achieved. The sluggish wheels of the economy make some people do not have the purchasing power and power to reach out to tourism itself. Another challenge faced is a health facility that must be provided by tourism management. It's not an easy thing carried out considering it is related to culture people who are still low regarding hygiene, awareness of the importance of maintaining health is still questionable. 


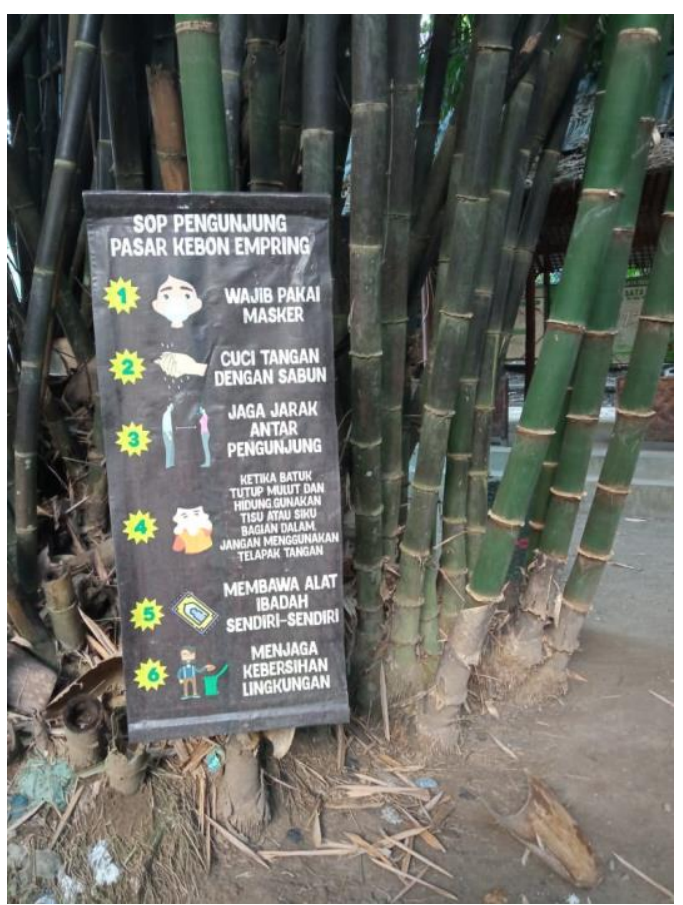

Figure 5. Health Protocol of PKE

Meanwhile, the challenges faced by the PKE management are related to a decrease in tourist visits. This certainly has an effect on the decline of the economy. One of them is in the tourism sector. One of the efforts to survive in pandemic is to make a new plan. This means that business actors must be able to keep the company alive with various promotional efforts carried out during the pandemic. In addition, more visit promotions directed at nature tourism which is indeed the location open and avoid crowds to prevent the transmission of the covid-19 virus. Selling affordable ticket prices, providing a variety of promos and discounts as well as free masks for all tourists who use our services are also carried out as an effort to minimize challenges faced during the pandemic. ${ }^{20}$ 


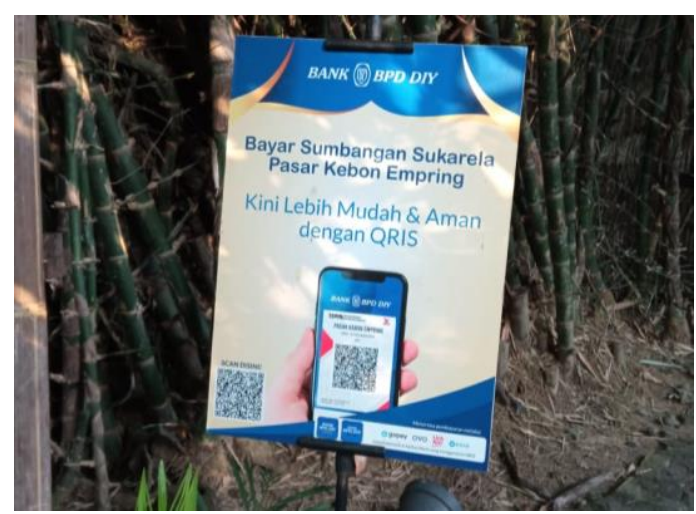

Figure 6. Contactless Payment Method

\section{Conclusion}

Brand Positioning, Brand Personality, and Brand Identity is a mutual branding effort complement each other. These three brands are carried out through the promotion of tourism by the use of mass media, both mainstream media as well as online media. Usually, promotions can be carried out in crowded places such as exhibitions, music concerts, bazaars, and so on, however, during this pandemic, promotions can only be done through the media, especially social media.

The challenges faced by PKE are inseparable from the spread of Covid 19 which is also hit almost all districts in Bantul. PKE travel branding challenges include economic reasons to reduce the power buying, including visiting tourist sites. Another challenge relates to lack of disciplined public health protocols around tourist areas, low public awareness about the importance of cleanliness, less assertive tourism officers in acting against visitors who do not comply with health protocols, and the lack of health facilities and task force of covid-19 at PKE.

\section{References}

[1] Indeks Daya Saing Pariwisata Indonesia."available on https://travel.kompas.com/read. [accessed on 21 July 21] and "Wisata Indonesia di Mata Dunia." Available on https://indonesia.go.id/ragam/pariwisata. [Accessed on 21 July 2021]

[2] S.S. Wachyuni dan D.A. Kusumaningrum, "THE EFFECT OF COVID-19 PANDEMIC: HOW ARE THE FUTURE TOURIST BEHAVIOR?” J. of Education, and Behavioral Science, vol. 33, no. 4, hlm. 67-76, 2020. 3. "Masuk daftar Paling Terdampak Covid-19. Sektor Pariwisata Perlu Direcovery Segera." Available on https://www.liputan6.com/news/read/4093273/masuk-daftar-paling-terdampak-covid19-s ektor-pariwisata-perlu-direcovery-segera.

[3] "This is how coronavirus could affect the travel and tourism industry." Available on: https://www.weforum.org/: https://www.weforum.org/agenda/2020/03/ world-travel-coronavirus-covid19-jobs- pandemic-tourism-aviation. Accessed on 21 July 2021.

[4] Masruroh. (2018). Analisis Branding Dalam Upaya Pengembangan Destinasi Wisata Religi Sunan Drajat. Pasca Sarjana UIN Surabaya (digilib.uinsby.ac.id) 
[5] Susanto, H. d. (2004). Power Branding: Membangun Merek Unggul dan Organisasi Pendukungnya. Jakarta: PT Mizan Republika.

[6] Prayudi. (2012). Public Relations Stratejik. Yogyakarta: CV Pandan Mas.

[7] Tjiptono, F. (2005). Pemasaran Jasa, edisi pertama. Yogyakarta: Bayu Media Publishing

[8] Kotler, K. L. (2009). Manajemen Pemasaran Edisi 13 Jilid I trans. oleh Bob Sabran. Jakarta: Airlangga.

[9] Sunaryo, B. (2013). Kebijakan Pembangunan Destinasi Pariwisata Konsep dan Aplikasinya Di Indonesia. Yogyakarta: Gava Med

[10] Suharsimi, A. (2006). Prosedur Penelitian Suatu Pendekatan Praktik. Jakarta: Rineka Cipta

[11] William, R.L. \& Omar, M. (2014). How Branding Process Activities Impact Branding Equity Within Higher Education Institutions. Journal of Marketing for Higher Education, 24(1), 1-10.

[12] Anholt, S. (2008). Palce Branding: Is it marketing, or isn't it?. Place Branding and Public Diplomacy, 4(1), 1-6

[13] Assenov, I and Khurana,N. (2012). Social Media Marketing and the Hospitality Industry: Evidence from Thailand. International Conference on Business and Management, Phuket, Thailand, 6-7 September,pp. 325-335. 